\title{
WHO IS RESPONSIBLE FOR THE POSITIVE NET MIGRATION IN THE REPUBLIC OF MACEDONIA?
}

DOI: http://dx.doi.org/10.18509/GBP.2018.32 UDC: 314.15(497.7)"1994/2016"

\author{
Biljana Apostolovska Toshevska \\ Mirjanka Madjevikj \\ Marija Ljakoska \\ University of "Ss Cyril and Methodius" - Skopje, Faculty of natural sciences and mathematics, \\ Institute of geography, Macedonia
}

\begin{abstract}
The scope, intensity and direction of migration are directly related to the dynamics of the socio-economic development. Therefore, they can be considered as one of the significant factors affecting the number of the population and the population structure. Considering the geographical, historical, socio-economic, religious and political conditions, the territory of the Republic of Macedonia has always been affected by intensive migration movements, by frequent extensive emigration movements of its inhabitants, but also immigration of people from other countries, i.e. foreigners.

In this paper is analyzed the number of migrants, only foreigners. In the last couple of years have recorded significant growth, causing significant changes in the structure of immigrants according the country of origin. The focus of this paper is put on the countries from which the immigrants choose the Republic of Macedonia as an attractive destination to stay and also what is their distribution all over the country, some of their demographic characteristics and their impact on the demographic processes.
\end{abstract}

Keywords: migrants, foreigners, net migration, country of origin, demographic characteristics, Republic of Macedonia

\section{INTRODUCTION}

In the vocational literature that considers migration as a demographic phenomenon and process, there are various definitions of what it represents and they are all essentially related to the spatial mobility of the population and the changing place of residence. The term migration or resettlement includes all changes of the places of permanent residence, whether it's resettlement with a permanent or temporary character, on a lesser or greater distance, within or outside state and administrative borders. Today, most researchers agree that the change of place of residence means at least moving to another settlement considered as an administrative unit or independent settlement [15]. When this movement takes place outside the state borders, it is considered as international migration.

Simply defined, migration can be explained as a result of "the human response to the economic, social and demographic environment that surrounds it, so that their versatility is motivated by the desire to satisfy their own need or avoid some difficulty." [10]. In the direction of explaining migration in science, more theoretical views on the type, causes and consequences of migrations have been developed. According to the civil theories about international migrations, the spatial mobility of the population is a reaction to the fact that in another surrounding, living conditions can be improved and some needs can 
be met. Therefore, they have two dimensions: spatial and temporal, which makes the observations more complex [25].

In contemporary conditions, international population migration is closely related to the demographic and socio-economic development and the migration policy of the countries from where migrants come from, and the countries where the migrants are staying temporary or permanently. In both spatial areas they have a significant influence on the scope and structure of the population.

The Republic of Macedonia located in the Southeast of Europe, on the Balkan Peninsula is a region that is characterized by significant international routes passing, which are the bases for a traffic connection with the neighbouring countries and beyond. Such geostrategic position at certain times was an occasion for encouraging numerous migration movements in different directions and scope. In the past, combined with the historical, social, political and socio-economic circumstances, the colonization policies that led to it, the desire to assimilate its population, the struggle for political and economic domination defined the direction and extent of the immigration of a foreign population of its territory.

In the repeated history, especially in the period after the Republic of Macedonian becoming independent, the voluntary immigration of a foreign population is evident and it has various motives for migration, such as employment, education, marrying a citizen of the Republic of Macedonia, investing in certain areas, political reasons, etc. The conditions for entry, stay and leaving the country, as well as the rights and obligations that they have during the stay, are defined by the Law on Foreigners (Official Gazette of the Republic of Macedonia No. 35/2006; 66/2007; 117/2008; 92/2009; 156/2010; $84 / 2012 ; 158 / 2011 ; 13 / 2013 ; 147 / 2013 ; 217 / 2015)$ [14] and the subordinate regulations. The Law on Employment and Work of Foreigners (Official Gazette of the Republic of Macedonia No. 70/2007, 5/2009; 217/15) and the subordinate regulations define the procedures and conditions under which foreigners can work in the country, "with the exception when it is defined by an international agreement" [16].

In conditions when there is a high percentage of the emigration of the citizens of the Republic of Macedonia, the immigration of the foreign population comes to terms and is the main reason for the positive net migration in Macedonia. Such a situation, which in no part, (given from the demographic, social, economic and political point of view), is not negligible, is the reason that kindles the interest in research. On the other hand, despite the possibility of manipulating specific numbers, there are illegal immigrants, which not only influence the demographic, social and economic image of the country, but also bring new challenges for the country related to its political stability and security.

Hence, the main task of this paper is to investigate which population immigrates, the reason for immigration and how this will reflect on the characteristics of the total population in the near future, but also the impact on certain segments in the economy.

The paper aims to contribute to the perception of contemporary demographic trends in the country and to point out the need for a professionally shaped migration policy.

This study is in favour of perceiving the situation when it comes to immigration issues in the Republic of Macedonia.

\section{PREVIOUS RESEARCH}

The complexity and diversity of the territorial redistribution of the population are the basis through which one can observe and perceive a large number of phenomena in the environment in which they occur. Migrations are a significant component on which the 
dynamics and structure of the population in a particular area depends. They have the character of a complex socio-economic process.

The spatial redistribution of the population is in the focus of the scientific interest of geographers because of the fact that migrants are of particular significance for perceiving and understanding the demographic processes that took place in the past or are current today. The migration movements in the Republic of Macedonia that took place in the past and left mark on its demogeographic development were studied by several researchers. In the geographical literature, can be found papers in which the authors studied the connection of migrations with the demographic development of the population within the entire state or its separate areas. Jovan Trifunoski (1952, 1955, 1956, 1958, 1963), [26], [27], [28], [29], [30], conducted the field research on immigration in the middle of the twentieth century in many areas in Macedonia. There are also researches for the migration processes in the rural area of Skopje Valley (Daskalovski, 1993) [3], and for the population distribution and its characteristics in the Skopje Valley (Panov, 1976) [17], for the demographic development of the population in the Republic of Macedonia during the twentieth century (Daskalovski, 1995) [4] and the tendencies in the demographic development, (Daskalovski, 2001) [6], for the immigration and development of the urban population in Skopje Valley (Daskalovski, 2001) [5], for the dynamics of the world population with a review on the Republic of Macedonia (Madjevikj, 2009) [12], for the Bosniaks (Stojmilov and Apostolovska Toshevska, 2008) [24], and Ramchilovikj, 2005 [18], for the immigration of Albanians, Trifunoski (1988) [31], for the emigration and immigration in the country (Madjevikj et. al, 2016) [13], for the internal migration (Apostolovska Toshevska, Ljakoska, 2016) [1], as well as the papers of the economists about the permanent migration processes in Macedonia, (Kjurchiev, 1985) [11], Janeska [10] and other.

\section{RESEARCH METHODOLOGY AND DATA SOURCES}

In the paper, the research mainly refers to the immigration of persons from other countries on the territory of the Republic of Macedonia. Methodological explanations and interpretations are used according to the State Statistical Office (SSO). The term "place of temporary residence of a foreigner" covers the place where a foreigner has settled in with the purpose of temporarily residing on the territory of the Republic of Macedonia. The duration of each foreigner's stay is limited depending on the kind of the permit issued on the basis of relevant documentation [22], [23].

The study of migrations, especially the migration of foreigners, is followed by serious difficulties in the methodological aspect and in terms of the data scope and type. The insufficient scope of comparable migration statistics is an important limiting factor in the research. In the paper were used data from administrative sources.

The administrative data sources are data on migration flows and cover the number of citizens and foreigners entering or leaving the Republic of Macedonia during one calendar year. These numbers are obtained from the relevant services of the Ministry of Interior [14], published by the State Statistical Office in annual statistical reviews. The time series for foreigners marks its beginning since 1994 (the electronic MakStat data base) [20] until 2000).

Foreigners are considered as a unique category of foreigners from 1994 to 2005, so that since 2006, according to the statistical records of the State Statistical Office, the two statistical categories of data are included: foreigners with temporary residence and 
foreigners with an extended stay. Due to the limited data access, the spatial aspect analysis of immigration was obtained on the basis of immigrated foreigners with temporary stay. Also, for the migration analysis were used data from the International Organization for Migration (IOM) [9], and the conducted poll analysis of transit migrants in Macedonia from August 2015 till February 2016, when Macedonia announced refugee crisis (19th August 2015).

The analysis for the foreigner's stay in Macedonia and the recorded work permits, especially in the period from 2006 to 2016 (applications for work permits, employment permits, by activity and occupations, educational attainment, country of origin, and the city where the applications for work permits were requested), is made according to the Employment Service Agency of the Republic of Macedonia (ESARM) data. The research period is selected due to the uniform methodology for classifying migration data. A disadvantage is the ability to analyze data by municipalities, due to the different territorial organization that has changed several times during the 23 -year analysed period.

\section{RESULTS AND DISCUSSION}

For the population of the Republic of Macedonia, traditionally inherent is the territorial mobility, i.e., moving from one place to another for different reasons. In this context, migrations take place not only within the country, but it is also evident the migration outside the country. At the same time, although the Republic of Macedonia is a country with a slowly evolving economy, migrations directed toward it are still noticed. This research focuses on the period from the end of the twentieth century to the present. It is a period when serious political and economic changes in the country and the immediate surroundings took place. The Republic of Macedonia gaining its independence was followed by major social and demographic changes, including the spatial movement of the population both within and outside the country.

Table 1. Immigrated and emigrated citizens

of the Republic of Macedonia and foreigners in the period 1994-2016

\begin{tabular}{|c|c|c|c|c|c|c|c|c|}
\hline \multirow[b]{2}{*}{ Year } & \multicolumn{5}{|c|}{ Immigrated } & \multicolumn{3}{|c|}{ Emigrated } \\
\hline & Total & $\begin{array}{l}\text { Citizens of } \\
\text { the R. } \\
\text { Macedonia }\end{array}$ & $\begin{array}{l}\text { Foreigners- } \\
\text { temporary } \\
\text { stay }\end{array}$ & $\begin{array}{l}\text { Foreigners- } \\
\text { extended } \\
\text { stay }\end{array}$ & $\begin{array}{l}\text { Foreigners- } \\
\text { Total }\end{array}$ & Total & $\begin{array}{l}\text { Citizens of } \\
\text { the R. } \\
\text { Macedonia }\end{array}$ & $\begin{array}{l}\text { Foreigners- } \\
\text { temporary } \\
\text { stay }\end{array}$ \\
\hline 1994 & 3433 & 1651 & 1782 & 0 & 1782 & 478 & 424 & 54 \\
\hline 1995 & 2088 & 1128 & 960 & 0 & 960 & 392 & 359 & 33 \\
\hline 1996 & 1489 & 850 & 639 & 0 & 639 & 247 & 220 & 27 \\
\hline 1997 & 1295 & 739 & 556 & 0 & 556 & 282 & 254 & 28 \\
\hline 1998 & 1057 & 595 & 462 & 0 & 462 & 248 & 241 & 7 \\
\hline 1999 & 1118 & 658 & 460 & 0 & 460 & 141 & 127 & 14 \\
\hline 2000 & 1199 & 639 & 560 & 0 & 560 & 172 & 165 & 7 \\
\hline 2001 & 1185 & 458 & 727 & 0 & 727 & 503 & 312 & 191 \\
\hline 2002 & 1257 & 723 & 534 & 0 & 534 & 141 & 81 & 60 \\
\hline 2003 & 1145 & 567 & 578 & 0 & 578 & 144 & 112 & 32 \\
\hline 2004 & 1381 & 543 & 838 & 0 & 838 & 669 & 656 & 13 \\
\hline 2005 & 1491 & 524 & 967 & 0 & 967 & 1300 & 1282 & 18 \\
\hline 2006 & 3273 & 545 & 1029 & 1699 & 2728 & 1108 & 1073 & 35 \\
\hline 2007 & 2181 & 366 & 861 & 954 & 1815 & 240 & 224 & 16 \\
\hline 2008 & 1609 & 219 & 557 & 833 & 1390 & 751 & 740 & 11 \\
\hline 2009 & 1857 & 259 & 1000 & 598 & 1598 & 792 & 769 & 23 \\
\hline 2010 & 2715 & 303 & 1356 & 1056 & 2412 & 1007 & 923 & 84 \\
\hline 2011 & 3211 & 349 & 1747 & 1115 & 2862 & 1290 & 1143 & 147 \\
\hline 2012 & 3787 & 396 & 2072 & 1319 & 3391 & 1415 & 1330 & 85 \\
\hline 2013 & 3991 & 490 & 1941 & 1560 & 3501 & 1041 & 945 & 96 \\
\hline 2014 & 4208 & 265 & 2273 & 1670 & 3943 & 839 & 740 & 99 \\
\hline 2015 & 5358 & 259 & 3617 & 1482 & 5099 & 1016 & 767 & 249 \\
\hline 2016 & 4743 & 283 & 2481 & 1979 & 4460 & 630 & 440 & 190 \\
\hline
\end{tabular}

Source: www.stat.gov.mk [20] 
In the international migration movements in the analyzed period from 1994 to 2016, 69,917 persons were included or an average of 3,040 persons per year. Dominant are the migrations directed towards the country, i.e. $78.8 \%$ were immigration movements, and 21.2\% were emigration movements. The citizens of the Republic of Macedonia participated with $90 \%$ in the emigration movements, that is, an average of 579 citizens per year.

Out of the total number of immigrants, 12,809 were citizens of the Republic of Macedonia, and 42,262 were foreigners (out of which 27,997 foreigners with temporary stay and 14,265 foreigners with extended stay) or a ratio of 1:3 in favour of foreign immigrants. The ratio between the immigrated foreigners and emigrated citizens of the Republic of Macedonia (13,327 emigrated citizens in the period 1994-2016) indicates that in the period of 23 years, per every emigrated citizen of the Republic of Macedonia, three or more people immigrate from abroad. In the period from 1994 to 2016, an average of 1,800 foreigners immigrated in the Republic of Macedonia per year. Even $80 \%$ immigrated in the period from 2005 to 2016. The share of immigrated foreigners in the total number of immigrants is significant. It starts to grow from 2006, and in the period from 2010 to 2016 it participates in the total number of immigrants with an average of $89 \%$.

In detail, during the analysed period from 1994 to 2016, in the Republic of Macedonia was recorded a positive net migration of 40,225 persons. Only 1994 stand out, as the year when the citizens of the Republic of Macedonia are still immigrating from other republics of former Yugoslavia, which in some part in the previous years were occupied with military unrest and conflicts.

Table 2. Total net migration, net migration of the citizens

of the Republic of Macedonia and foreigners in the period 1994-2016

\begin{tabular}{rrrr}
\hline \multirow{2}{*}{ Year } & \multicolumn{3}{c}{ Net migration } \\
\cline { 2 - 4 } & Total & Citizens of the Republic of Macedonia & Foreigners \\
\hline $\mathbf{1 9 9 4}$ & 2955 & 1227 & 1728 \\
\hline $\mathbf{1 9 9 5}$ & 1696 & 769 & 927 \\
\hline $\mathbf{1 9 9 6}$ & 1242 & 630 & 612 \\
\hline $\mathbf{1 9 9 7}$ & 1013 & 485 & 528 \\
\hline $\mathbf{1 9 9 8}$ & 809 & 354 & 455 \\
\hline $\mathbf{2 0 0 0}$ & 977 & 531 & 446 \\
\hline $\mathbf{2 0 0 1}$ & 1027 & 474 & 553 \\
\hline $\mathbf{2 0 0 2}$ & 682 & 146 & 536 \\
\hline $\mathbf{2 0 0 3}$ & 1116 & 642 & 474 \\
\hline $\mathbf{2 0 0 4}$ & 1001 & 455 & 546 \\
\hline $\mathbf{2 0 0 5}$ & 712 & -113 & 825 \\
\hline $\mathbf{2 0 0 6}$ & 191 & -758 & 949 \\
\hline $\mathbf{2 0 0 7}$ & 2165 & -528 & 2693 \\
\hline $\mathbf{2 0 0 8}$ & 1941 & 142 & 1799 \\
\hline $\mathbf{2 0 0 9}$ & 858 & -521 & 1379 \\
\hline $\mathbf{2 0 1 0}$ & 1065 & -510 & 1575 \\
\hline $\mathbf{2 0 1 1}$ & 1708 & -620 & 2328 \\
\hline $\mathbf{2 0 1 2}$ & 1921 & -794 & 2715 \\
\hline $\mathbf{2 0 1 3}$ & 2372 & -934 & 3306 \\
\hline $\mathbf{2 0 1 4}$ & 2950 & -455 & 3405 \\
\hline $\mathbf{2 0 1 5}$ & 3369 & -475 & 3844 \\
\hline $\mathbf{2 0 1 6}$ & 4342 & -508 & 4850 \\
\hline & 4113 & -157 & 4270 \\
\hline & & Source: www.stat.gov.mk [20]
\end{tabular}

As a result of the positive net migration for both, the citizens of the Republic of Macedonia and foreigners there was a positive total net migration up to 2003. Since 2004, 
the ratio of the causes of the positive net migration has changed in favour of the positive net migration of the foreign immigrants. On the other hand, the negative net migration among the citizens of the Republic of Macedonia shows continuity, from the fact that after 1990, the largest number of emigration from the Republic of Macedonia as permanent family emigration and family reunification has been recorded [19].

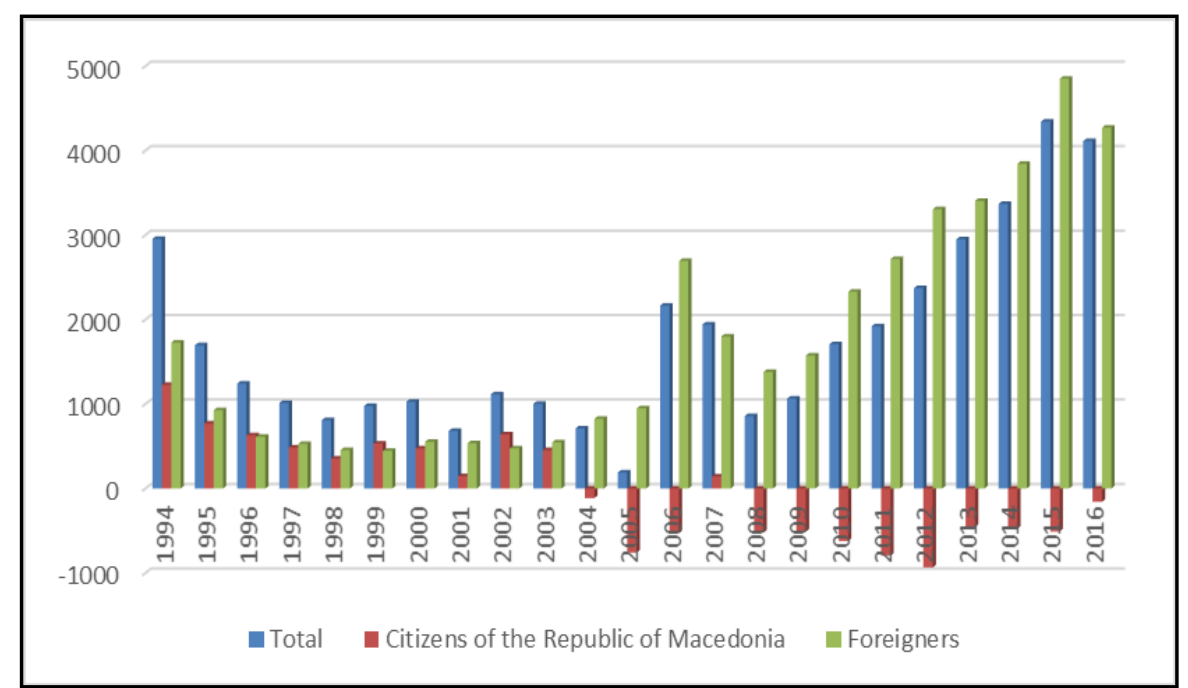

Figure 1. Net migration (total, citizens of the Republic of Macedonia, foreigners), 1994-2016 Source: Calculated according www.stat.gov.mk data [20]

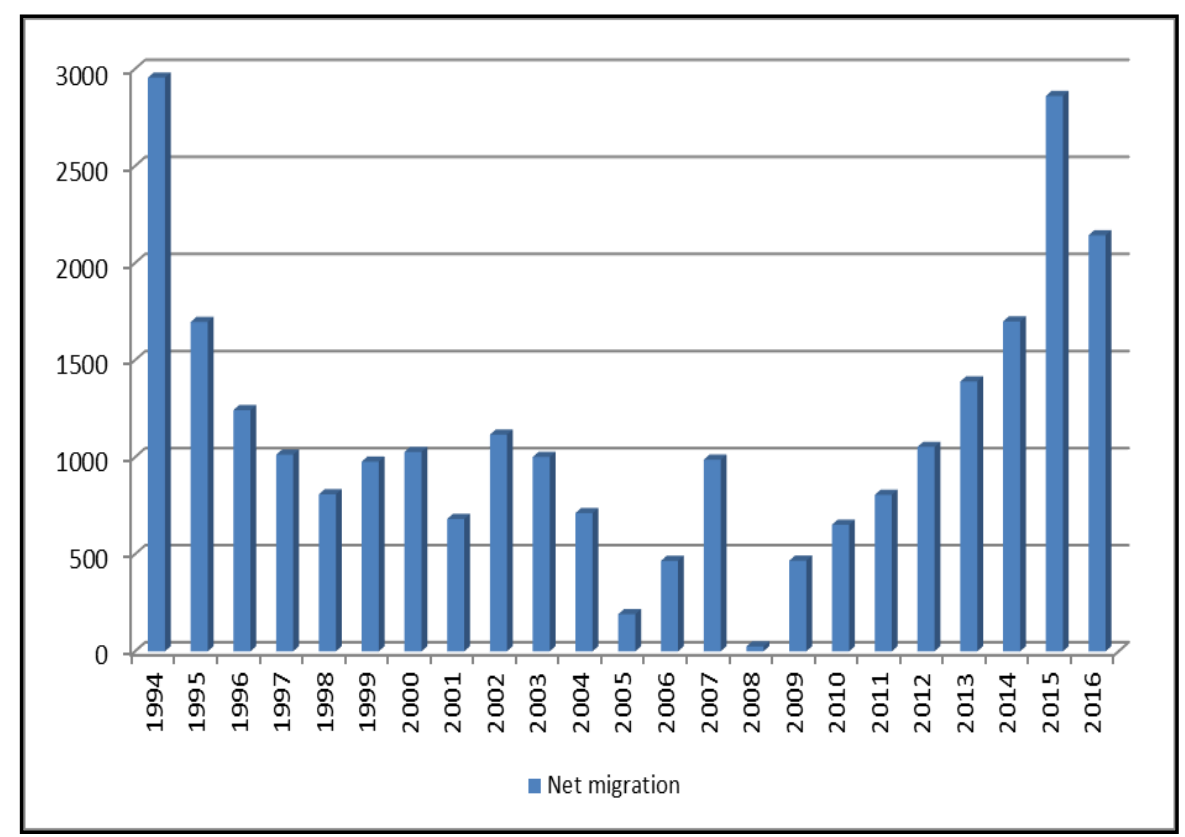

Figure 2. Total net migration, 1994-2016

Source: www.stat.gov.mk

In the study of migrations, the spatial aspect occupies a significant place. The analysis of the immigrated foreigners, according to the spatial distances from which they immigrate is of particular interest. In this case, we confirm our previous findings that the largest number of migrants originates from our immediate surroundings. In the period from 2005 to 2016, 88.9\% of immigrants were from Europe. Most of the immigrants were from Albania, Turkey and Kosovo, and their share of the total number of immigrants has 
especially increased from 2007 to 2015 . The reasons for their immigration are different, but are related to the smaller spatial distance, employment opportunities or the development of their own business, marriage, education, etc., supported and facilitated by family and friends.

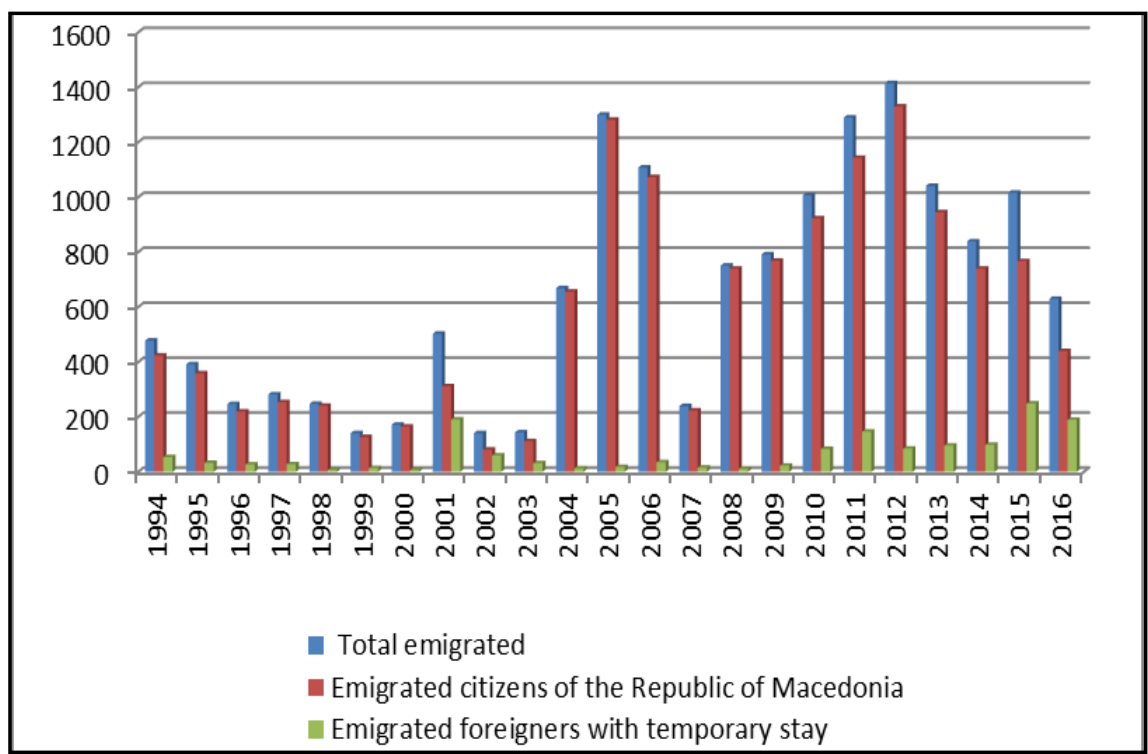

Figure 3. Absolute participation of the citizens of the Republic of Macedonia and foreigners with temporary stay in the total number of emigrants, 1994-2016

Source: www.stat.gov.mk

Because of getting married to a citizen of the Republic of Macedonia, by the beginning of the nineties of the last century, a significant number of foreigners were from Bulgaria, the counters that belonged to the former Soviet Union, Romania, Poland, Hungary and Czech Republic. Since 1992, it is characteristic the immigration of young girls from Albania that are getting married with Macedonian citizens [8].

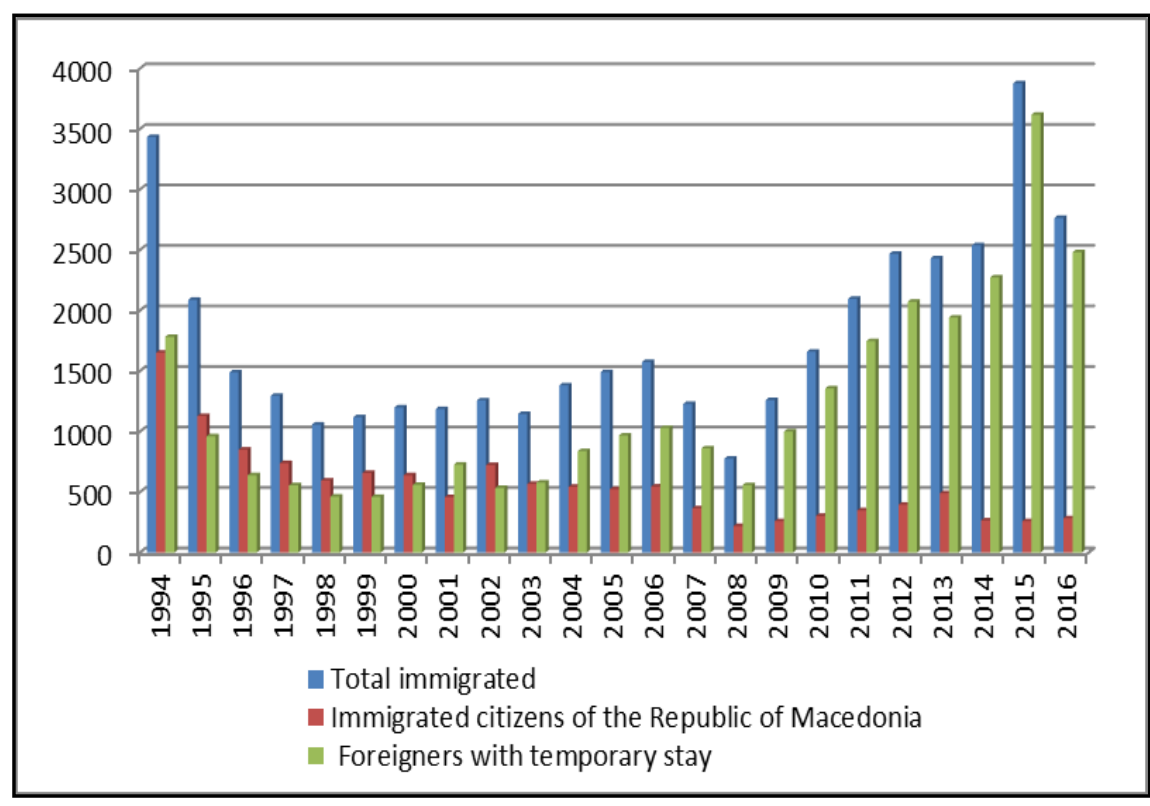

Figure 4. Absolute participation of the citizens of the Republic of Macedonia and foreigners with temporary stay in the total number of immigrants, 1994-2016

Source: www.stat.gov.mk 
According to the ESARM data, from 2002 to 2007, 5,867 employment approvals for foreigners were issued, of which 2,080 were new demands [16]. From 2008 to 2015, the total number of this type of approvals has been constantly increasing and during the entire period, a total of 17,176 permits were issued, out of which 10,729 were new [7]. The indicated period of increase in the work permits of foreigners to a large extent coincides with the period of more intensive positive net migration growth of foreigners in the Republic of Macedonia.

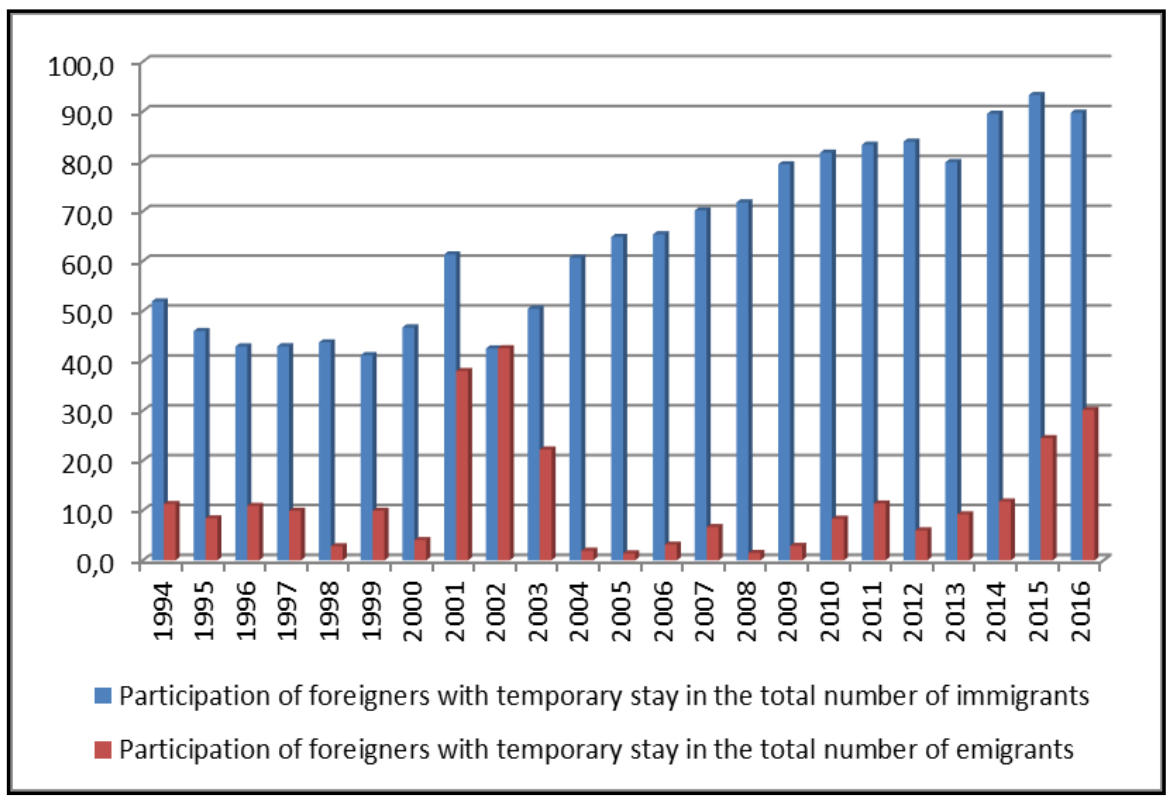

Figure 5. The participation of foreigners with temporary stay in the total number of immigrated and emigrated persons, 1994-2016

Source: www.stat.gov.mk

Most of the persons who received work permits have completed secondary and primary education, and according to the country of origin, they mostly come from Turkey (21.6\%), Greece $(14.3 \%)$ and Serbia (11.9\%).

In the case of persons with temporary stay, it is usually a matter of employment or marriage. Emigration based on employment has been encouraged by the FDI in the Republic of Macedonia. More precisely, in this period, the campaign for the promotion of the Republic of Macedonia through business forums (marketing campaigns - Invest in Macedonia and Macedonia Timeless) as a favorable business destination for foreign investors. Particular emphasis was put on the efforts for investments in the industry. With tax and customs benefits and purpose-built infrastructurally prepared locations, certain Greenfield and Brownfield investments were established. Some of the investments were in the form of acquisitions and mercenaries (transfer of the existing capital from the local domestic company to or from a foreign company). In that way, more industrial companies are investing in Macedonia such as Johnson Control, Johnson Matthey, TeknoHose, Kemet Electronics, Van Hool, ODV Electric, Markart, Draexlmaier, Kromberg \& Schubert etc., [2]. The employment in new companies certainly has created opportunities for immigration of individual foreigners, who were mostly part of the management team of investors.

If an analysis of the spatial distribution of the immigrated foreigners in the country is made only on the basis of the obtained work permits, the greater attractiveness of the 
larger cities is noted and in that context their concentration in the larger urban centers where there are more favorable conditions for conducting a business. Most of the work permits were issued in Skopje, in the period from 2008 to 2015, even $70 \%$ of the total number of work permits. Followed by Gevgelija, Tetovo, Bitola etc.

Changes are also evident among persons who have received residence in the country due to education. The involvement of foreigners in the educational process in the Republic of Macedonia was also characteristic in the past when a large number of students from the former SFRY and other countries were educated at the universities in Macedonia.

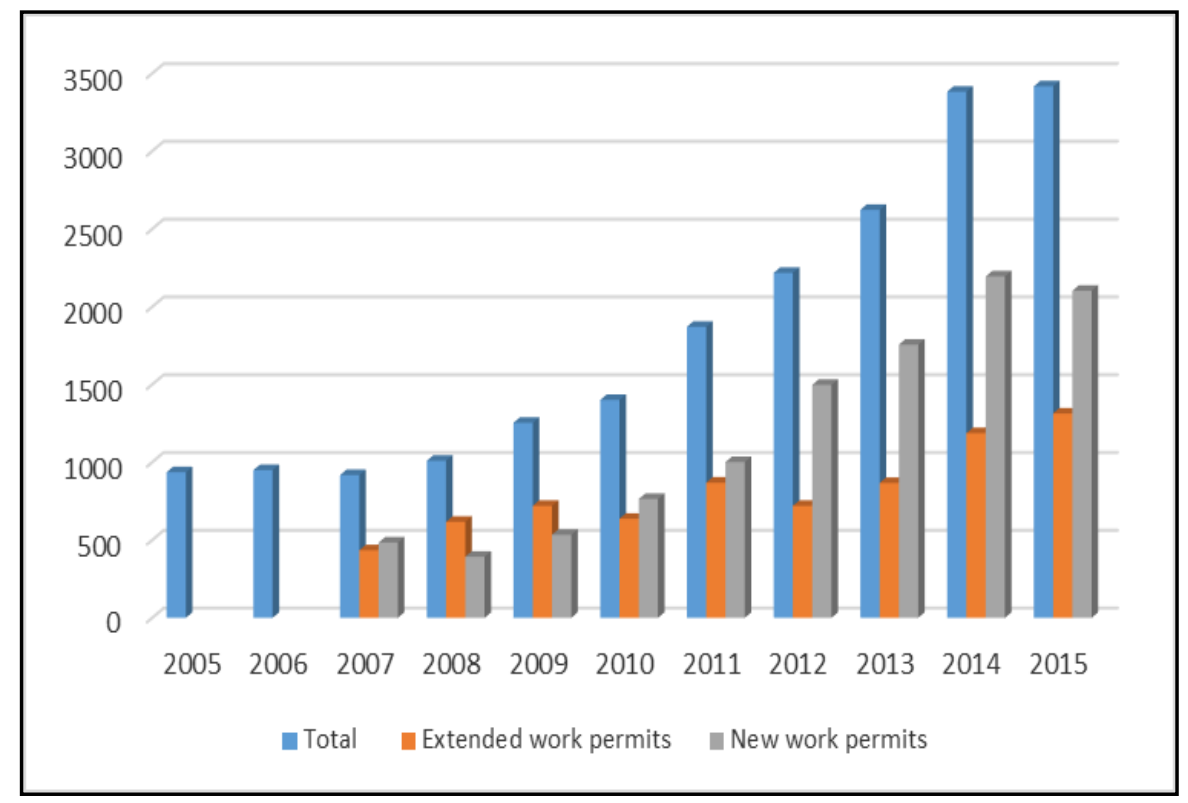

Figure 6. Absolute ratio of work permits issued by the ESARM, 2008-2015

Source: Calculated according the ESARM annual reports, 2008-2015, www.avrm.gov.mk [7]

Following the collapse of Yugoslavia, a large number of students with a temporary stay permit who studied at the Universities in Macedonia, based on student exchange agreements, returned to their country of origin. Some of the students lost their scholarships, so during 1991 and 1992, all foreign students from the African countries, and a large number of students from the Near East, Iran, Iraq, Syria and Jordan, left the Republic of Macedonia [8]. Therefore, during the 1990s, this number was declining, but in recent years, there have been noticeable changes in upward trends. Based on the education, the number of enrolled students in undergraduate studies increases. From the academic year $2007 / 08$ to $2015 / 16$ a total of 14,655 foreign students enrolled the undergraduate study programs, and by the end of 2016/17 their number was 17,628 students. Their share of the total number of enrolled students is increasing from $2.1 \%$ in the academic year 2007/08 to $4.6 \%$ in $2015 / 16$ and 5.1\% in 2017/18. During the entire analyzed period, one third were from Serbia, (although their number has dropped by 2 times from the beginning to the end of the analyzed period), $21.5 \%$ were from Kosovo and $44 \%$ from other countries, many of which were from Turkey.

The reported data on the number of immigrated foreigners in the country are mainly from the official statistics and refer only to the registered events. Large numbers of people who have not been recorded can be added to this number. Taking into account the geographic position of the state and especially its location on the Balkan route of migrants, it would be also interesting to analyze the persons who at one moment stayed in our territory, that 
is, the Republic of Macedonia was a transit country to them. For some of them, Macedonia may be the ultimate destination.

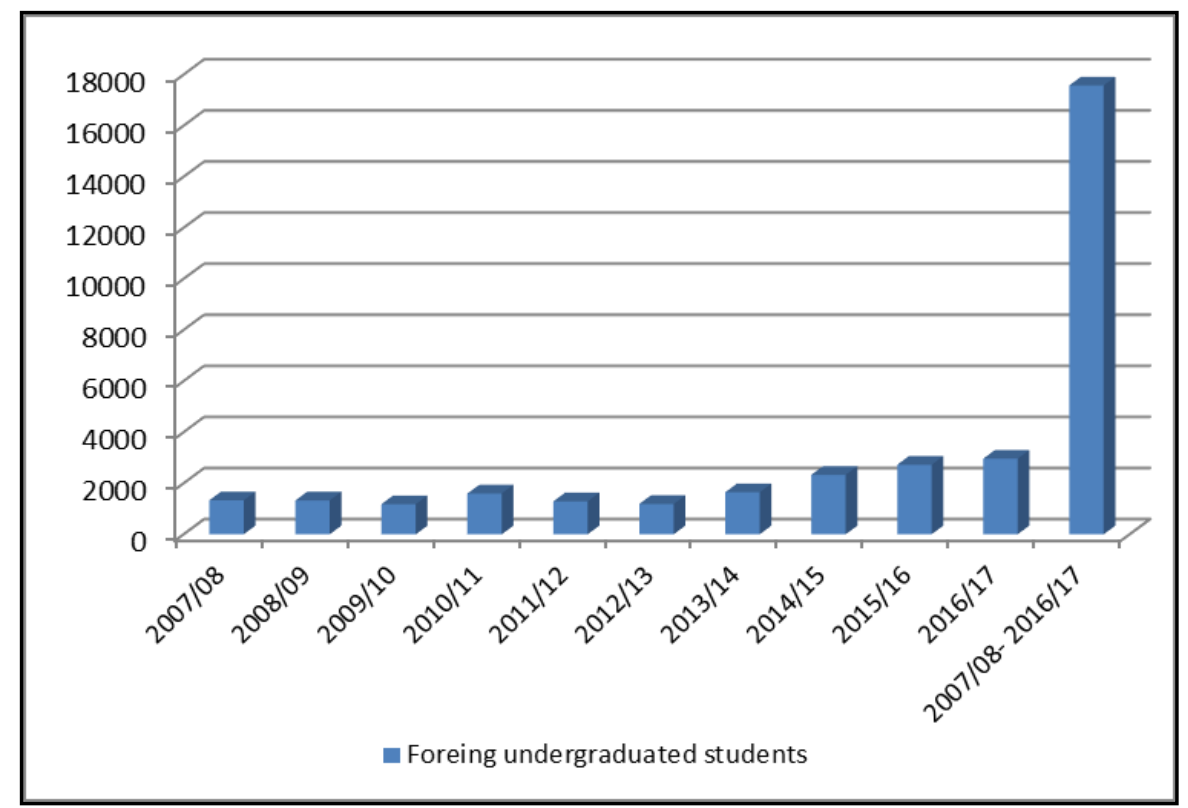

Figure 7. Foreign undergraduate students

Source: www.stat.gov.mk

According to the IOM data, only between August 2015 and February 2016, on average, 8,200 migrants per day passed through Macedonia. About $60 \%$ of them were from Syria and then Afghanistan, Iraq, etc. In the shelters in the southern and northern border, there are only 40 people now. In the Macedonian shelters up to 2,000 people could stay for a few hours and that is 1,500 in Gevgelija on the southern border and 500 people in the shelter in Tabanovce on the northern border.

According to IOM and Eurostat in 2015, 130,730 immigrants were recorded in Macedonia which represents $6.29 \%$ of the overall population of the country. Half of them or 67,799 are from Albania, 19,922 from Turkey, 17,930 from Serbia, 9,229 from Montenegro, and 8,713 from Bosnia and Herzegovina.

\section{INFLUENCE AND CONSEQUENCES}

The migration policy and the control of the scope, the type and the direction of immigration, are of particular importance for the country. It should separately define and analyze the different types of foreign citizens, because their number, material and financial condition and motives for migration are different and may have a different effect on the Macedonian society in general, now and in the future. The complex character of international migration is reflected through their influence and the consequences they pose in the demographic, social, economic and political life, both in the country of origin and in the country where they arrived.

The Macedonian economy is benefiting more from the immigration of a foreign population with better material and financial basis, because they stimulate the economy, in spite of the effect of low income foreigners, whose salaries is mainly returned to their 
families and make foreign currency exports. Special attention should be paid to foreigners who have short-term investments that can cause economic damage to the country [16]. The involvement is evident also on the basis of social implications in the state. The reception of persons with a difficult economic situation opens up the possibility of burdening the social system of the state, which is a concrete problem on its own.

In Macedonia, in the past, besides emigration, there were numerous immigrations of persons originating from territories and states outside the current state borders. Given the main goal of the research in which the accent is placed on immigration in the Republic of Macedonia in the period since it gained its independence, it is necessary to perceive the consequences of immigration from several aspects. When it comes to the connection of immigration and emigration to the population change in a given area, the scope of migration should be taken into account and what is their ratio to the total population.

Migrations as one of the key components of the population dynamics have an impact on its change in terms of dynamics in number and structure. The results of the migration movements that took place in Macedonia in the period 1994-2016 indicate a different structure of the number of immigrants, where the number of immigrated foreigners is dominant, compared to the smaller participation of the citizens of Macedonia.

Such a situation shaped the Republic of Macedonia as a country attractive to immigration, but to a smaller number of immigrants compared to the highly developed countries. However, such a situation, when going on continuously and in a longer period of time, has serious consequences on the population number and its distribution. Regarding the selectivity of migrations according to certain population characteristics, changes in the structure of the population are expected in this direction, such as: gender, age, nationality, language, religion, economy, etc. The impacts will be more pronounced if one takes into consideration the fact that, when analyzed the demographic characteristics of the people emigrating from the country can be noted, that for the most part the young working age Macedonian population is emigrating. Emigration in combination with the low population natural increase in the country has left serious consequences. According to the latest data referring to 2016, the number of emigrated citizens of the Republic of Macedonia abroad was 440 persons, that is $17 \%$ of the total population natural increase in the country.

The negative trends are especially felt among persons of the Macedonian ethnic affiliation who already have a negative population natural increase, i.e. in 2016 the number of deaths was 3,044 persons more than the number of livebirths by mothers of the Macedonian ethnic affiliation [21]. All of this affects the structure of the population, according to ethnicity and further on, decreases the participation of the Macedonian population in the total population in the country.

At the same time, the number of immigrated foreigners with only a temporary stay in 2016 was 2,481 persons and was only one hundred persons less than the population natural increase in the country in the same year. If we add the number of immigrants with an extended stay of 1,979 persons to this number, it will be obvious that the immigration of foreigners exceeds the population natural increase in the country, and if that trend continues, it will grow into a major component in the changes of the population number. The migration of a young working age population has a certain influence on the age structure of the population, but also on the economic structure, employment and so on. 


\section{CONCLUSION}

The obtained results from the migration research in the Republic of Macedonia over the past years point to the serious changes that have taken place in the migration flows. It is obvious that, as in the previous period, out-of-country migration is still ongoing and the emigration contingent is composed of young, educated and qualified population from different professional profiles. At the same time, Macedonia remains attractive for immigration of some of the population from its immediate surroundings, that is, from neighboring countries and Turkey as well as from other countries on different grounds. It is essential that in the analyzed period the immigration of foreigners prevails in the migration scope, while the number of Macedonian citizens is smaller. The reasons for immigration are diverse and mainly include employment and development of own business, marriage, education and family reasons. The increase in the number of immigrants, in conditions when the population natural increase in the country is extremely low, imposes many questions. In such circumstances, the implications of the immigration to the demographic, social and economic development of the country should be considered. It is not very favorable for the country if the foreign immigration becomes a dominant component of the country's population growth. The current immigration rate that in recent years has been around two people per one thousand inhabitants if it is maintained at that level or continues to increase will have implications on the demographic development of the country. This will directly affect the total population number and its structure according to the ethnic and religious affiliation and changes in the biological and economic structure. The economic effects require additional research because they can have positive effects on the economy of the country to a certain extent, but if it comes to immigration of a larger number of people that remains economically inactive, then the situation is not very favorable. Due to the complex impact of migrations on the overall development of the country, particular attention should be given to immigration, while creating the migration policy, that is, precise determination of immigration requirements, determination of the scope of immigration, monitoring and directing migration flows and so on. In any case, they should not be allowed to take place spontaneously, uncontrolled and without directions from the relevant institutions.

"The programs and measures in this direction should rely on the scientific results, and their application and impact should be for the ultimate purpose: overcoming and improving the identified unfavorable conditions, processes and changes for a more rational and harmonized interaction with the previous disproportions of the socioeconomic and demographic development" (Daskalovski, 2000).

Creating a migration policy is an imperative in the development of every modern state, which on the one hand will protect the interests of the state and its population, while on the other hand it will be in correlation with the declaration of human rights and freedom. The need for measures pointed towards reducing emigration of young labour and reproductive population outside the country is only one segment of the migration policy. At the same time, in conditions of great movement and spatial mobility of the population on a wider scale, the state should have clearly built attitudes and standards in the terms of immigration. But, while emphasizing that a more pragmatic migration policy with more demands and barriers to migrants, should not be understood as a policy of isolation, inhumanity and alike, but as a procedure of caution and responsibility to the citizens of the Republic of Macedonia and the society as a whole. 


\section{REFERENCES}

[1] Apostolovska Toshevska B. \& Ljakoska M. Internal migratory movements and the (no) opportunities for sustainable development in the Republic of Macedonia, Proceedings of the second international scientific conference Geobalcanica 2016, 10-12.06.2016, Skopje, Republic of Macedonia, pp 331-338, 2016.

[2] Apostolovska Toshevska B. \& Ljakoska M. Structural and spatial (re) organization of the industry in the Republic of Macedonia in the 21st century, Proceedings of the third international scientific conference Geobalcanica 2017, 20-21.05.2017, Skopje, Republic of Macedonia, pp 271-278, 2017.

[3] Daskalovski V. Migration processes in the rural area of Skopje Valley. Annual, Book 31-32, Institute of geography, Skopje, Republic of Macedonia, pp 5-36, 1993.

[4] Daskalovski V. Demographic development of habitants in the Republic of Macedonia, Geographical Reviews, Tome 30, Skopje, pp 23-29, 1995.

[5] Daskalovski V. Population development of the urban population in Skopje Valley, Annual, Book 35-36, Institute of Geography, Skopje, pp 5-59, 2001.

[6] Daskalovski V. Tendencies in the demographic development of the Republic of Macedonia, Proceedings of the Second Congress of the Geographers of the Republic of Macedonia, Skopje, 2001.

[7] Employment Service Agency of the Republic of Macedonia (ESARM), Annual reports, 20082015, Skopje, Republic of Macedonia

[8] Government of the Republic of Macedonia, Strategy for the Integration of Foreigners and Refugees in the Republic of Macedonia 2008-2015, Skopje, Republic of Macedonia.

[9] IOM https://www.iom.int/

[10] Janevska V. Contemporary international migrations, emigration from the Republic of Macedonia and socio-economic development, Institute of Economics, Skopje, 2001.

[11] Kjurchiev A. Permanent migration of the population in SR Macedonia. Problems of Demographic Development in SR Macedonia, MANU, 3 - 4. 11. 1983, Leunovo, Skopje, 1985.

[12] Madjevikj M. Dynamics of the number of the World population with review of the Republic of Macedonia, Geographical Reviews, Book 43, Skopje, pp 67-83, 2009.

[13] Madjevikj M., Apostolovska Toshevska B., Gorin S. \& Ljakoska M. The regional differentiation of the demographic movements in the Republic of Macedonia, Environmental \& Socioeconomic Studies, Vol. 4, No 3/2016, Poland, pp 10-20, 2016.

[14] Ministry of interior www.mvr.gov.mk

[15] Nejašmić I. Demogeography: population in spatial relations and processes, Školska knjiga, Zagreb, 2005.

[16] Nikoloski Z. Migration-contraindications or cause for positive effects, Skopje, 2010.

[17] Panov M. Territorial distribution and population characteristics of Skopje Valley, FNSM, Annual volume, 19, Skopje, 1976.

[18] Ramchilovikj Z. Spatial distribution of Bisniaks in the Republic of Macedonia, Geographical review, No 40, pp 105-115, 2005

[19] Risteski S. Consequences and implications of International migration on the socio-economic and demographic development of the Republic of Macedonia. Annual of the faculty of economics - Skopje, 48C, pp 169-180, 2013.

[20] State statistical office of the Republic of Macedonia (SSORM),

http://www.stat.gov.mk 
[21] State statistical office of the Republic of Macedonia (SSORM), Natural population change, 2016, Skopje, Republic of Macedonia, 2017.

[22] State statistical office of the Republic of Macedonia (SSORM), Statistical overview: Population and social statistics 2.4.17.06 no. 875, 2016.

[23] State statistical office of the Republic of Macedonia, Statistical review; 2.4.17.07 (876), Skopje, Republic of Macedonia, 2017.

[24] Stojmilov A. \& Apostolovska Tosevska B. The number and spatial distribution of Bosniaks in the Republic of Macedonia, Geographical papers, Bosnia and Herzegovina, 2008.

[25] Šantić D. \& Spasovski M. Contemporary world migration - towards new terminology, patterns and policies, Bulletin of the Serbian geographical society, 96 (2), pp 5-17, 2016.

[26] Trifunoski, J. Macedonian families with Albanian origin in Polog, Annual Proceedings of the Faculty of Philosophy, history and philology department, No. 5, Skopje, 1952.

[27] Trifunoski, J. Skopje fields. Settlements and origin of the population, No.35, Belgrade, 1955.

[28] Trifunoski, J. Relocation of Sandzak Muslims in Macedonia, Bulletin of the Serbian Geographical Society, XXXVI (1), 61, Belgrade, 1956.

[29] Trifunoski, J. About the postwar colonization of the People's Republic of Macedonia and three Banat settlements - Jabuka, Kacharevo and Glogonj, Matica Srpska, special editions, Novi Sad, pp 5-43, 1958.

[30] Trifunoski, J. Slovenian immigrants from Albania, settled in Bitola-Prilep Valley, Annual Proceedings of Geography and Geology, 14 (2), Skopje, 1963.

[31] Trifunoski J. Albanian population in the Socialistic Republic of Macedonia. Kniževne Novine, Belgrade, Serbia, 1988. 